\title{
Gambaran hasil produk kalsium dan fosfor pada pasien penyakit ginjal kronik stadium V di Ruang Hemodialisis RSUP Prof. Dr. R. D. Kandou Manado
}

\author{
${ }^{1}$ Livia F. Yauri \\ ${ }^{2}$ Emma S. Moeis \\ ${ }^{2}$ Karel Pandelaki \\ ${ }^{1}$ Kandidat Skripsi Fakultas Kedokteran Universitas Sam Ratulangi Manado \\ ${ }^{2}$ Bagian Penyakit Dalam Universitas Sam Ratulangi Manado \\ Email: liviayauri_12231@yahoo.co.id
}

\begin{abstract}
Chronic kidney disease (CKD) is a pathological process with various etiology that causes a progressive reduction in kidney and generally ended with renal failure. In chronic renal failure, there are usually chronic complications such as anemia and bone disease with low level of calcium serum, high level of phosphorus serum, and high paratyroid hormone. This study was aimed to obtain the description of the levels of calcium and phosphorus serum in CKD patients at the hemodialysis unit in Prof. R. D. Kandou Hospital Manado. This was a descriptive study based on patient medical records. Of the 75 patients, the majority of them were males (41 patients; $54.7 \%$ ), aged $>60$ years (27 patients; $36 \%$ ), and had calcium serum level in normal limit (40 patients; 53.3\%) and phosphorus serum level as hyperphosphatemia (61 patients; 81.3\%).
\end{abstract}

Keywords: CKD, calcium serum, phosphorus serum, hemodialysis

\begin{abstract}
Abstrak: Penyakit ginjal kronik (PGK) adalah suatu proses patofisiologi dengan etiologi beragam yang mengakibatkan penurunan fungsi ginjal secara progresif, dan umumnya berakhir dengan gagal ginjal. Pada gagal ginjal kronik, biasanya terdapat komplikasi kronik meliputi anemia serta penyakit tulang, biasanya dengan kadar kalsium rendah, fosfat tinggi dan hormon paratiroid tinggi. Penelitian ini bertujuan untuk mengetahui gambaran hasil produk kalsium dan fosfat pada pasien penyakit ginjal kronik stadium $\mathrm{V}$ di ruang hemodialisis. Jenis penelitian ialah deskriptif dengan menggunakan data rekam medik dan dikelompokkan berdasarkan jenis kelamin, umur, kadar kalsium, dan kadar fosfor serum, hasil produk kalsium dan fosfat. Dari 75 sampel, didapatkan terbanyak ialah pasein berjenis kelamin laki-laki sebanayak 41 orang $(54,7 \%)$, rentang umur $>60$ sebanyak 27 orang (36\%), dengan kadar kalsium serum normal sebanyak 40 orang $(53,3 \%)$ dan kadar fosfor serum hiperfosfatemia yaitu 61 orang $(81,3 \%)$.
\end{abstract}

Kata kunci: penyakit ginjal kronik, hemodialisis, kalsium serum, fosfor serum.

Penyakit ginjal kronik (PGK) adalah suatu proses patofisiologi dengan etiologi yang beragam, mengakibatkan penurunan fungsi ginjal yang progresif, dan pada umumnya berakhir dengan gagal ginjal. Gagal ginjal adalah suatu keadaan klinis yang ditandai dengan penurunan fungsi ginjal yang irreversible yang memerlukan terapi pengganti ginjal berupa dialisis atau transplantasi ginjal. ${ }^{1}$ Dialisis adalah suatu proses difusi zat terlarut dan air secara pasif melalui suatu membran berpori dari satu kompartemen cair menuju ke kompartemen cair lainnya. Hemodialisis merupakan terapi pengganti ginjal yang dilakukan dengan mengalirkan darah ke dalam suatu 
tabung ginjal buatan (dialiser) yang bertujuan untuk mengeleminasi sisa-sisa metabolisme protein dan koreksi gangguan keseimbangan elektrolit antara kompartemen darah dan kompartemen dialisat melalui membran semipermeabel. ${ }^{2}$

Pada PGK, biasanya terdapat komplikasi kronik yang meliputi anemia akibat eritropoietin yang tidak adekuat, serta penyakit tulang, biasanya dengan kadar kalsium rendah, fosfat tinggi dan hormon paratinoid tinggi. Peningkatan hormon paratiroid (PTH) bisa terjadi akibat retensi fosfat, yang menyebabkan turunnya kalsium terionisasi. Akibat klinisnya ialah osteoporosis akibat hiperparatiroidisme, osteomalasia akibat kekurangan vitamin D dan kalsifikasi ektopik. ${ }^{3,4}$ Masalah jantung akibat hipokalsemia ialah penurunan kontraktilitas jantung. Kadar kalsium yang berlebihan meningkatkan penghambatan efek pada natrium dalam otot skelet. Hal ini menimbulkan penurunan eksitabilitas baik pada otot dan saraf, yang akhirnya menimbulkan flaksiditas. Hipokalsemia tersebut berasal dari menurunnya penyerapan kalsium di usus akibat menurunnya kalsitriol dan juga terkait dengan peningkatan fosfat atau hiperfosfatemia pada pasien PGK . ${ }^{5}$ Gagal ginjal merupakan penyebab tersering dari hiperfosfatemia. Hiperfosfatemia dapat diakibatkan oleh kurangnya eksresi fosfat melalui urin, asupan fosfat yang berlebihan, atau pelepasan fosfat dari sel. Peningkatan fosfat semakin menurunkan kalsium dengan menyebabkan deposit kalsium fosfat di jaringan yang menstimulasi peningkatan hormon paratiroid dan menyebabkan hiperparatiroid sekunder. ${ }^{3}$

Penelitian ini dilakukan untuk mengetahui gambaran kadar kalsium serum dan fosfat serum pada pasien PGK stadium $\mathrm{V}$ yang menjalani hemodialisis di unit Hemodialisis bagian Ilmu Penyakit Dalam RSUP Prof. R. D. Kandou.

\section{METODE PENELITIAN}

Jenis penelitian ialah deskriptif dengan menggunakan data sekunder. Penelitian dilakukan di Unit hemodialisis bagian/SMF Ilmu Penyakit Dalam RSUP Prof. Dr. R. D. Kandou Malalayang, Manado pada bulan Oktober-Desember 2015. Populasi penelitian ini ialah seluruh penderita PGK yang menjalani hemodialisis di unit hemodialisis RSUP Prof. Dr. R. D. Kandou Malalayang, Manado. Sampel penelitian ialah penderita PGK stadium $\mathrm{V}$ yang menjalani perawatan di ruang hemodialisis dengan variabel penelitian umur, jenis kelamin, kadar kalsium serum dan kadar fosfor serum.

Data dianalisis menggunakan software pengolahan data yaitu SPSS versi 20 kemudian setiap variabel penelitian dideskripsikan dengan menggunakan tabel untuk menggambarkan informasi secara umum tentang variabel penelitian.

\section{HASIL PENELITIAN}

Penelitian yang dilakukan pada bulan Oktober 2015 - Desember 2015 di Unit Hemodialisis RSUP Prof. Dr. R. D. Kandou Manado ditemukan 75 pasien PGK stadium $\mathrm{V}$ yang sedang menjalani hemodialisis dan telah melakukan pemeriksaan laboratorium kalsium serum dan fosfor serum. Distribusi kadar kalsium serum pada laki-laki berdasarkan kelompok umur didapatkan pasien sebanyak 41 orang. Pada kelompok umur $\leq 30$ tahun terdapat 1 pasien dengan kadar kalsium menurun $(2,44 \%)$, pada kelompok umur 31-40 tahun terdapat 2 pasien dengan kadar kalsium menurun dan 1 pasien kadar kalsium normal dengan total 3 orang $(7,32 \%)$, pada kelompok umur 41-50 tahun terdapat 5 pasien kadar kalsium menurun dan 5 pasien kadar kalsium normal dengan total 10 orang $(24,39 \%)$, pada kelompok umur 51 60 tahun terdapat 4 pasien kadar kalsium menurun dan 5 pasien kadar kalsium normal dengan total 9 orang $(21,95 \%)$, dan pada kelompok umur $>61$ tahun terdapat 9 pasien kadar kalsium menurun dan 9 pasien kadar kalsium normal dengan total 18 orang $(43,9 \%)$. Distribusi sampel dapat dilihat pada Tabel 1. 
Tabel 1. Distribusi kadar kalsium serum pada laki - laki berdasarkan kelompok umur

\begin{tabular}{lcccc}
\hline \multirow{3}{*}{ Kelompok Umur } & \multicolumn{3}{c}{ Kadar kalsium } & Total \\
\cline { 2 - 4 } & $\begin{array}{c}\text { Menurun } \\
(<\mathbf{8 , 3} \mathbf{~ m g} / \mathbf{d l})\end{array}$ & $\begin{array}{c}\text { Normal } \\
(\mathbf{8 , 3}-\mathbf{1 0 , 6} \mathbf{~ m g} / \mathbf{d l})\end{array}$ & $\begin{array}{c}\text { Meningkat } \\
(>\mathbf{1 0 , 6} \mathbf{~ m g} / \mathbf{d l})\end{array}$ & \\
\hline$\leq 30$ Tahun & 1 & 0 & 0 & 1 \\
31 - 40 Tahun & 2 & 1 & 0 & 3 \\
41 - 50 Tahun & 5 & 5 & 0 & 10 \\
51 - 60 Tahun & 4 & 5 & 0 & 9 \\
$>$ 60 Tahun & 9 & 9 & 0 & 18 \\
Total & 21 & 20 & 0 & 41 \\
\hline
\end{tabular}

Distribusi kadar kalsium serum pada wanita berdasarkan kelompok umur didapatkan pasien sebanyak adalah 34 orang. Pada kelompok umur $\leq 30$ tahun terdapat 1 pasien kadar kalsium menurun dan 1 pasien kadar kalsium normal dengan total 2 orang $(5,8 \%)$, pada kelompok umur 31-40 tahun terdapat 2 orang kadar kalsium menurun dan 2 orang kadar kalsium normal dengan total 4 orang $(11,76 \%)$, pada kelompok umur 41-50 tahun terdapat 3 orang kadar kalsium menurun dan 4 orang kadar kalsium normal dengan total 7 orang (20,59\%), pada kelompok umur 51=60 tahun terdapat 4 orang kadar kalsium menurun, 7 orang kadar kalsium normal, dan 1 orang kadar kalsium meningkat dengan total 12 orang $(35,29 \%)$, dan pada kelompok umur $>61$ tahun terdapat 3 orang kadar kalsium menurun dan 6 orang kadar kalsium normal dengan total 9 orang $(26,47 \%)$ (Tabel 2).

Tabel 2. Distribusi kadar kalsium serum pada perempuan berdasarkan kelompok umur

\begin{tabular}{lcccc}
\hline \multirow{2}{*}{$\begin{array}{l}\text { Kelompok umur } \\
\text { (Tahun) }\end{array}$} & $\begin{array}{c}\text { Menurun } \\
(<\mathbf{8 , 3} \mathbf{~ m g} / \mathbf{d l})\end{array}$ & $\begin{array}{c}\text { Kodar kalsium } \\
\mathbf{( 8 , 3 - 1 0 , 6 ~} \mathbf{~ m g} / \mathbf{d l})\end{array}$ & $\begin{array}{c}\text { Meningkat } \\
(>\mathbf{1 0 , 6} \text { mg/dl) }\end{array}$ & \\
\hline$\leq 30$ Tahun & 1 & 1 & 0 & 2 \\
31 - 40 Tahun & 2 & 2 & 0 & 4 \\
41 - 50 Tahun & 3 & 4 & 0 & 7 \\
51 - 60 Tahun & 4 & 7 & 1 & 12 \\
$>$ 60 Tahun & 3 & 6 & 0 & 9 \\
Total & 13 & 20 & 1 & 34 \\
\hline
\end{tabular}

Distribusi kadar fosfor serum pada pria berdasarkan kelompok umur mendapatkan pasien sebanyak adalah 41 orang. Pada kelompok umur $\leq 30$ tahun terdapat 1 pasien kadar fosfor normal $(2,4 \%)$, pada kelompok umur 31-40 tahun terdapat 3 pasien dengan kadar fosfor meningkat (7,32\%), pada kelompok umur 41-50 tahun terdapat 1 orang kadar fosfor normal dan 9 orang kadar fosfor meningkat dengan total 10 orang $(24,39 \%)$, pada kelompok umur 51-60 tahun terdapat 1 orang kadar fosfor normal, 8 orang kadar fosfor meningkat dengan total 9 orang $(21,95 \%)$, dan pada kelompok umur $>61$ tahun terdapat 1 orang kadar fosfor menurun dan 3 orang kadar kalsium normal, dan 14 orang dengan kadar fosfor meningkat dengan total 18 orang $(43,9 \%)$ (Tabel 3).

Distribusi kadar fosfor serum pada wanita berdasarkan kelompok umur mendapatkan pasien sebanyak adalah 34 orang. Pada kelompok umur $\leq 30$ tahun terdapat 2 pasien kadar fosfor meningkat (5,8\%), pada kelompok umur 31-40 tahun terdapat 4 pasien dengan kadar fosfor meningkat $(11,76 \%)$, pada kelompok umur 41-50 tahun terdapat 2 orang kadar fosfor 
normal dan 5 orang kadar fosfor meningkat dengan total 7 orang $(20,59 \%)$, pada kelompok umur 51-60 tahun terdapat 3 orang kadar fosfor normal, 9 orang kadar fosfor meningkat dengan total 9 orang $(35,29 \%)$, dan pada kelompok umur $>61$ tahun terdapat 1 orang kadar fosfor menurun dan 3 orang kadar kalsium normal, dan 14 orang dengan kadar fosfor meningkat dengan total 18 orang $(26,47 \%)$ (Tabel 4).

Tabel 3. Distribusi kadar fosfor pada laki - laki berdasarkan kelompok umur

\begin{tabular}{|c|c|c|c|c|}
\hline \multirow{2}{*}{$\begin{array}{l}\hat{0} \\
\text { Kelompok Umur } \\
\text { (Tahun) }\end{array}$} & \multicolumn{3}{|c|}{ Kadar fosfor serum } & \multirow[t]{2}{*}{ Total } \\
\hline & $\begin{array}{c}\text { Menurun } \\
(<2,7 \mathrm{mg} / \mathrm{dl})\end{array}$ & $\begin{array}{c}\text { Normal } \\
(2,7-4,5 \mathrm{mg} / \mathrm{dl})\end{array}$ & $\begin{array}{c}\text { Meningkat } \\
(>\mathbf{4 , 5} \mathrm{mg} / \mathrm{dl})\end{array}$ & \\
\hline$\leq 30$ Tahun & 0 & 1 & 0 & 1 \\
\hline $31-40$ Tahun & 0 & 0 & 3 & 3 \\
\hline $41-50$ Tahun & 0 & 1 & 9 & 10 \\
\hline $51-60$ Tahun & 0 & 1 & 8 & 9 \\
\hline$>60$ Tahun & 1 & 3 & 14 & 18 \\
\hline Total & 1 & 6 & 34 & 41 \\
\hline
\end{tabular}

Tabel 4. Distribusi kadar fosfor pada wanita berdasarkan kelompok umur

\begin{tabular}{lcccc}
\hline++ & \multicolumn{3}{c}{ Kadar fosfor serum } & Total \\
\cline { 2 - 4 } $\begin{array}{l}\text { Kelompok Umur } \\
\text { (Tahun) }\end{array}$ & $\begin{array}{c}\text { Menurun } \\
(<\mathbf{2 , 7} \mathbf{7 m} / \mathbf{d l})\end{array}$ & $\begin{array}{c}\text { Normal } \\
(\mathbf{2 , 7}-\mathbf{4 , 5} \mathbf{~ m g} / \mathbf{d l})\end{array}$ & $\begin{array}{c}\text { Meningkat } \\
(>\mathbf{4 , 5} \mathbf{~ m g / d l})\end{array}$ & \\
\hline$\leq 30$ Tahun & 0 & 0 & 2 & 2 \\
31 - 40 Tahun & 0 & 0 & 4 & 4 \\
41 - 50 Tahun & 0 & 2 & 5 & 7 \\
51 - 60 Tahun & 0 & 3 & 9 & 12 \\
$>$ 60 Tahun & 0 & 2 & 7 & 9 \\
Total & 0 & 7 & 27 & 34 \\
\hline
\end{tabular}

Distribusi hasil produk kalsium dan fosfat berdasarkan jenis kelamin dari pasien PGK stadium V di Unit Hemodialisis RSUP Prof. Dr. R. D. Kandou Manado mendapatkan angka kejadian terbanyak pada laki-laki yaitu 41 orang $(54,7 \%)$ dibanding perempuan yaitu 34 orang $(45,3 \%)$.

Pada distribusi hasil produk kalsium serum menurut jenis kelamin, didapatkan pasien terbanyak adalah dengan nilai kalsium normal, yaitu 40 orang $(53,3 \%)$.
Pasien dengan hipokalsemia didapatkan sebanyak 34 orang $(45,3 \%)$ vdan pasien dengan hiperkalsemia sebanyak 1 orang $(1,3 \%)$.

Pada distribusi hasil produk fosfor serum didapatkan pasien terbanyak adalah pasien dengan hiperfosfatemia yaitu 61 orang $(81,3 \%)$, pasien dengan kadar fosfor serum normal berjumlah 13 orang $(17,3 \%)$ dan pasien dengan hipofosfatemia berjumlah 1 orang $(1,3 \%)$.

Tabel 5. Distribusi hasil produk kalsium berdasarkan jenis kelamin

\begin{tabular}{lcccc}
\hline Hasil Produk & \multicolumn{3}{c}{ Kadar Kalsium Serum } & Total \\
\cline { 2 - 4 } & $\begin{array}{c}\text { Menurun } \\
(<\mathbf{8 , 3} \mathbf{~ m g} / \mathbf{d l})\end{array}$ & $\begin{array}{c}\text { Normal } \\
\mathbf{( 8 , 3}-\mathbf{1 0 , 6} \mathbf{~ m g} / \mathbf{d l})\end{array}$ & $\begin{array}{c}\text { Meningkat } \\
(>\mathbf{1 0 , 6} \mathbf{~ m g} / \mathbf{d l})\end{array}$ & \\
\hline Laki - Laki & 21 & 20 & 0 & 41 \\
Perempuan & 13 & 20 & 1 & 34 \\
Total & 34 & 40 & 1 & 75 \\
\hline
\end{tabular}


Tabel 6. Distribusi hasil produk fosfor berdasarkan jenis kelamin

\begin{tabular}{lcccc}
\hline Hasil produk fosfor & \multicolumn{3}{c}{ Kadar fosfor serum } & \multirow{2}{*}{ Total } \\
\cline { 2 - 4 } & $\begin{array}{c}\text { Menurun } \\
(<\mathbf{2 , 7} \mathbf{m g} / \mathbf{d l})\end{array}$ & $\begin{array}{c}\text { Normal } \\
(\mathbf{2 , 7}-\mathbf{4 , 5} \mathbf{~ m g} / \mathbf{d l})\end{array}$ & $\begin{array}{c}\text { Meningkat } \\
(>\mathbf{4 , 5} \mathbf{~ m g} / \mathbf{d l})\end{array}$ & \\
\hline Laki- Laki & 1 & 6 & 34 & 41 \\
Perempuan & 0 & 7 & 27 & 34 \\
Total & 1 & 13 & 61 & 10 \\
\hline
\end{tabular}

\section{BAHASAN}

Berdasarkan hasil penelitian deskriptif, pasien PGK yang sedang menjalani hemodialisis di unit hemodialisis RSUP Prof R. D. Kandou Manado yang dilakukan selama bulan Oktober-Desember 2015 didapatkan 75 pasien yang melakukan pemeriksaan kadar kalsium serum dan fosfor serum. Pada Tabel 1, distribusi kadar kalsium serum pada laki-laki berdasarkan kelompok umur didapatkan dari 41 pasien terbanyak dengan kadar kalsium serum menurun (hipokalsemia) dan berdasarkan umur, didapatkan paling banyak adalah pada rentang usia $>60$ tahun dengan jumlah pasien 27 orang. Seiring dengan bertambahnya usia, fungsi organ tubuh kerjanya akan semakin berkurang, dan dalam hal ini sesuai dengan hasil penelitian yang didapatkan bahwa angka kejadian terbanyak PGK adalah pada orang dengan usia 50 tahun keatas dibandingkan usia 50 tahun ke bawah. ${ }^{1}$ Pada PGK akan terjadi hipokalsemia yang memicu aktivitas kelenjar paratiroid. Hipokalsemi tersebut berasal dari menurunnya penyerapan kalsium di usus akibat menurunnya kadar kalsitriol dan juga terkait terhadap peningkatan kadar fosfat yang terdapat pada pasien PGK. ${ }^{6}$

Pada Tabel 2, distribusi kadar kalsium serum pada perempuan berdasarkan kelompok umur didapatkan dari 34 pasien terbanyak dengan kadar kalsium serum normal. Hampir semua kalsium di dalam tubuh $(99 \%)$ disimpan dalam tulang dan hanya $1 \%$ dalam cairan intraselular, dan $0,1 \%$ dalam cairan ekstrasel. Bila konsentrasi kalsium cairan ekstraselular turun dibawah normal, kelenjar paratiroid akan langsung dirangsang oleh kadar untuk meningkatkan sekresi hormon paratiroid hasil akhir berupaya kehilangan massa tulang.. Hormon ini akan langsung bekerja untuk meningkatkan resopsi garam-garam tulang, dan oleh karena itu, melepaskan sejumlah besar kalsium ke dalam cairan ekstraselular, sehingga mengembalikan kadar kalsium ke nilai normal. ${ }^{7}$

Pada Tabel 3 dan Tabel 4, distribusi kadar kalsium serum pada laki-laki dan perempuan berdasarkan kelompok umur masing-masing mendapatkan pasien terbanyak dengan kadar fosfat meningkat (hiperfosfatemia). Gagal ginjal merupakan penyebab tersering hiperfosfatemia berat. Oleh karena itu PTH meningkatkan eksresi fosfat, maka hipoparatiroidisme dapat menyebabkan hiperfosfatemia. ${ }^{3}$ Hal ini menyebabkan turunnya vitamin $\mathrm{D}$ aktif dan respons tulang terhadap kelenjar hiperparatiroid sehingga pasien akan berisiko mengalami komplikasi GMT-PGK ataupun gangguan kardiovaskular.

Pada Tabel 5, distribusi hasil produk kalsium dan fosfat berdasarkan jenis kelamin dari pasien PGK stadium V yang menjalani hemodialisis, didapatkan angka kejadian terbanyak pada laki-laki $(54,7 \%)$ dibandingkan perempuan $(45,3 \%)$. Hal ini hampir sama juga didapatkan oleh Wirhan et al. ${ }^{8}$ pada tahun 2006 yang meneliti 58 orang penderita PGK yang menjalani hemodialisis dengan perbandingan laki-laki dan perempuan 1,7 : 1, sedangkan Kumala et al. ${ }^{9}$ pada tahun 2008 di Jakarta melaporkan perbandingan laki-laki dan perempuan ialah $2: 1$.

\section{SIMPULAN}

Berdasarkan hasil penelitian dapat disimpulkan bahwa mayoritas pasien PGK 
stadium $\mathrm{V}$ yang menjalani hemodialisis di unit hemodialisis Bagian Ilmu Penyakit Dalam RSUP Prof. R. D. Kandou mempunyai kadar fosfor meningkat (hiperfosfatemia) dan kadar kalsium normal.

\section{SARAN}

1. Dilakukan penanganan untuk mengontrol keseimbangan cairan dan elektrolit pada pasien, sehingga tidak terjadi hipokalsemia dan hiperfosfatemia agar pasien dapat menghindari komplikasi lebih lanjut.

2. Penelitian lanjut mengenai hubungan antara kalsium dan fosfat pada pasien PGK stadium $V$ yang sedang menjalani hemodialisis di Unit Hemodialisis RSUP Prof. Dr. R. D. Kandou Manado.

\section{DAFTAR PUSTAKA}

1. Suwitra Ketut. Gagal Ginjal Kronik. In: Sudoyo AW, Setiyohadi B, Alwi I, Simadibrata M, Setiadi S, penyunting. Buku Ajar Ilmu Penyakit Dalam (5th ed). Jakarta: Interna Publishing, 2009; p. 1035-40.

2. Price SA, Wilson LM. Pengobatan Gagal Ginjal Kronik. In: Patofisiologi: Konsep Klinis Proses-proses Penyakit jilid 2 (6th ed). Jakarta: EGC, 2005; p. 912-91.

3. O'Callaghan C. Gagal Ginjal Kronik dan Renal Bone Disease. In: At a Glance Sistem Ginjal (3nd ed). Jakarta: Erlangga, 2009; p. 92-3.

4. David R, David W, Bradley J. Dalam: Lecture Notes on Clinical Medicine (6th ed). Jakarta: Erlangga, 2007.

5. Harjanto DD, Saraswati MR, Suastika K. A Case of Severe Hypocalcemia Secondary to Acquired Hypoparathyroidism. Journal of Internal medicine. 2008;9(2):134-43.

6. Santoso D. Gangguan Mineral Tulang pada Penyakit Gagal Ginjal Kronik. Surabaya: Airlangga University Press (AUP), 2015.

7. Brenner BM, Lazarus JM. Prinsip-prinsip Ilmu Penyakit DalamVolume 3 (13th ed). Jakarta: EGC, 2000.

8. Wirhan, Pramono B, Asdie AH. The differences of body mass index on depression in type 2 diabetes melitus at Dr. Sardijito hospital Yogyakarta. Palembang. Indonesian Journal of Internal Medicine. 2006:278-80.

9. Kumala M, Lukito W, Sastroamijoyo S Prodjosudjadi W. Fat free mass index as parameter of nutritional status in non dialysis CKD patients stage 3, 4 and 5. Med Journal Indonesian. 2008; 17(4):240-7. 